Марина Сна

Галина Кузнєцова

Володимир Рибальченко

\title{
Морфофункціональний стан ободової кишки щурів за умов дії похідних піролу на тлі експериментального коліту
}

Досліджено вплив цитостатиків похідних піролу 1-(4-Cl-бензил)-3-Cl-4-(CF-феніламіно)-1Н-пірол-2,5діону (МІ-1) та 5-аміно-4-(1,3-бензотіазол-2-іл)-1-(3-метоксифеніл)-1,2-дигідро-3Н-пірол-3-ону (Д1) при окремій та сумісній дії на морфо-функціональний стан слизової оболонки ободової кишки щурів за умов розвитку експериментального коліту. Встановлено, що М1 є більш ефективним і менш токсичним для слизової оболонки порівняно з Д1 та комбінації Д1 і МІ-1.

Ключові слова: слизова оболонка, ободова кишка, похідні піролу, експериментальний коліт.

Постановка наукової проблеми та їі значення. Запальні захворювання кишечника (ЗЗК), до яких належить виразковий коліт (ВК), є однією із найбільш серйозних і невирішених проблем сучасної гастроентерології. За важкістю перебігу та частотою ускладнень ЗЗК займають одне із провідних місць в структурі хвороб шлунково-кишкового тракту $[1 ; 2 ; 3]$. ВК - це запальне рецидивне хронічне захворювання товстої кишки, для якого характерні дистрофічні та атрофічні зміни слизової оболонки, що супроводжуються розладом секреторної, моторної функції та порушенням травлення [4]. Етіологія цього захворювання достеменно невідома, серед причин називають спадковість, алергічні реакції, неправильне харчування, тривале застосування нестероїдних протизапальних засобів, тощо [2; 4]. Наслідком хронічного ВК є підвищення ризику розвитку злоякісних новоутворень - колоректального раку, що підтверджено епідеміологічними дослідженнями [1; 5-7], тобто ВК можна вважати передраковим станом.

Відомо, що пухлинний ріст часто супроводжується ознаками запалення як у пухлинних вузлах, так і у прилеглій умовно нормальній тканині [8-10]. Дослідження наслідків тривалого впливу нестероїдних протизапальних засобів, що застосовуються при ЗЗК, показало значне зменшення кількості випадків колоректального раку у цільовій групі $[5 ; 11 ; 12]$. Встановлено також, що сигнальні шляхи запалення та канцерогенезу мають спільні ланки, зокрема NFkB [13]. Отже, блокада сигнальних шляхів, що зумовлюють розвиток запального процесу, може впливати на ініціацію i/чи прогресію пухлин, в тому числі колоректальних, і навпаки, інгібування сигнальних шляхів, що активуються при канцерогенезі, не може не вплинути на розвиток запалення $[13 ; 15]$.

У наших попередніх дослідженнях [8-10; 16-20] встановлено, що похідні піролу 1-(4-Clбензил)-3-Cl-4-(CF -феніламіно)-1Н-пірол-2,5-діон (MI-1) та 5-аміно-4-(1,3-бензотіазол-2-іл)-1-(3-метоксифеніл)-1,2-дигідро-3Н-пірол-3-он (Д1), синтезовані методом in silico дизайну в Науково-виробничому хіміко-біологічному центрі Київського національного університету імені Тараса Шевченка як таргетні інгібітори протеїнкіназ [21], проявляють протипухлинну активність при хімічно-індукованому раку товстої кишки щурів [22]. Також встановлено, що вказані сполуки сприяють зменшенню запалення, що супроводжує розвиток раку та оксидативного стресу [16; 23-25]. Таким чином, дослідження впливу похідних піролу на розвиток експериментального коліту $є$ перспективним як 3 погляду розширення уявлень про механізми дії вказаних сполук, так і з погляду застосування за умов передракових станів для попередження злоякісного переродження клітин слизової оболонки товстої кишки.

Мета статті - вивчити вплив похідних піролу на стан слизової оболонки товстої кишки щурів за умов експериментального коліту.

Матеріали та методи дослідження. Дослідження проводили на білих нелінійних щурах-самцях із початковою масою тіла 207 г, яких утримували в стандартних умовах віварію. Всі роботи було проведено відповідно до принципів біоетики, законодавчих норм та положень «Европейської конвенції про захист хребетних тварин, які використовуються для дослідних та наукових цілей» (Страсбург, 1986), «Загальних етичних принципів експериментів на тваринах», ухвалених Першим національним конгресом біоетики (Київ, 2001).

(C) Сна М., Кузнєцова Г., Рибальченко В., 2015 
Дослід тривав два тижні. Експериментальну модель виразкового коліту відтворювали двократним ректальним введенням 1мл $4 \%$ розчину оцтової кислоти з інтервалом один тиждень. Попередньо тваринам очищали товсту кишку, вводячи ректально 2-3 мл фізрозчину і масажуючи нижню частину черева для полегшення випорожнення за 10-15 хв до введення оцтової кислоти. МІ-1 у дозі 2,7 мг/кг та Д1 у дозі 2,3 мг/кг вводили щоденно per os, розчиненими у соняшниковій олії, що містить $15 \%$ ДМСО (всього 0,1 мл). Перше введення сполук здійснювали через 2 години після першого введення оцтової кислоти. Контрольні тварини отримували відповідні розчинники. Було сформовано п'ять груп (n = 7): I - контроль, II - експериментальний коліт, III - коліт +Д1, IV - коліт + MI-1, V - коліт + Д1 + MI-1. Щурів умертвляли через добу після останнього введення речовин за допомогою інгаляції з $\mathrm{CO}_{2}$ та цервікальної дислокації.

Для гістологічних досліджень брали сегменти товстої кишки (низхідна ободова кишка), які фіксували у $10 \%$ нейтральному сольовому формаліні, виготовляли парафінові зрізи та забарвлювали гематоксиліном-еозином за стандартною методикою [26]. Препарати аналізували на світлооптичному рівні за допомогою мікроскопа Olympus BX41 (Olympus Europe $\mathrm{GmbH}$, Японія), кольорові мікрофотографії отримували за допомогою цифрової фотокамери Olympus C-5050 Zoom (Olympus Europe $\mathrm{GmbH}$, Японія) та вказаного мікроскопа. Оцінювали загальний стан слизової оболонки низхідної ободової кишки, підраховували відносну кількість келихоподібних клітин та мітотичний індекс клітин у криптах. Морфометричні дослідження проводили за допомогою програми WCIF ImageJ. Вимірювали товщину слизової оболонки, глибину та ширину крипт, висоту колоноцитів, площу поперечного перетину келихоподібних клітин та ядер колоноцитів.

Статистичну обробку експериментальних даних здійснювали методами варіаційної статистики [27] за допомогою пакету програм SPSS 16.0: дані перевіряли на нормальність розподілу за допомогою Z-тесту Колмогорова-Смірнова, міжгрупові порівняння здійснювали методом однофакторного дисперсійного аналізу (ANOVA) з використанням для апостеріорних множинних порівнянь F-критерію Фішера, а також за допомогою U-тесту Манна-Уїтні. Різниця між значеннями показників, що порівнювались, вважалась вірогідною при $\mathbf{p} \leq 0,05$.

Виклад основного матеріалу й обгрунтування отриманих результатів дослідження. У щурів контрольної групи слизова оболонка низхідної ободової кишки має типову гістологічну будову, що характерна для цього виду піддослідних тварин, без ознак патологічних станів. Морфометричні дані представлено в таблиці 1.

Вплив індукованого коліту на слизову оболонку низхідної ободової кишки щурів.

При огляді щурів з індукованим колітом спостерігалися скуйовджена шерсть тварин, «мокрий хвіст», неоформлені випорожнення, що є явними ознаками діареї. Крім цього, при гістологічному описі препаратів ободової кишки були помітні дифузна десквамація поверхневого епітелію слизової оболонки, набряк та лімфо-інфільтрація власної пластинки. Крипти були переповнені слизом, їхні входи заповнені продуктами розпаду епітелію. Спостерігалися зміни судинного русла у вигляді вираженої гіперемії, міграції лейкоцитів, діапедезних крововиливів та кровостазів. У серозному шарі також мали місце запалення, набряк, розширення кровоносних капілярів та подекуди крововиливи. Порівняно з контролем вірогідних змін морфометричних показників не спостерігалося, що вказує на відсутність атрофічних змін у клітинах слизової оболонки. Згідно з літературними даними, такі явища свідчать про розвиток коліту без атрофії $[1 ; 3 ; 7 ; 28]$.

Таблиця 1

Морфометричні показники слизової оболонки низхідної ободової кишки щурів при дії похідних піролу за умов виразкового коліту $(\mathrm{M} \pm \mathbf{m})$

\begin{tabular}{|l|c|c|c|c|c|}
\hline \multirow{2}{*}{\multicolumn{1}{|c|}{ Показники }} & \multicolumn{5}{|c|}{ Назва групи } \\
\cline { 2 - 6 } & Контроль & Коліт & Коліт Д1 & Коліт МІ-1 & Коліт Д1+МI-1 \\
\hline $\begin{array}{l}\text { Товщина слизової } \\
\text { оболонки, мкм }\end{array}$ & $588,5 \pm 93,8$ & $648,7 \pm 103,6$ & $776,0 \pm 87,4 *$ & $667,5 \pm 133,6$ & $791,0 \pm 115,2^{*}$ \\
\hline Глибина крипт, мкм & $252,2 \pm 26,0$ & $265,2 \pm 36,4$ & $285,6 \pm 34,0$ & $233,8 \pm 23,4$ & $253,0 \pm 53,6$ \\
\hline Ширина крипт, мкм & $31,5 \pm 4,8$ & $30,7 \pm 4,4$ & $28,2 \pm 3,6$ & $30,2 \pm 3,4$ & $27,1 \pm 4,2$ \\
\hline Висота колоноцитів, мкм & $17,2 \pm 3,6$ & $17,4 \pm 2,6$ & $14,6 \pm 2,6$ & $16,0 \pm 2,2$ & $17,2 \pm 8,8$ \\
\hline
\end{tabular}


РОЗДІЛ IV. Фізіологія людини і тварин. 2, 2015

\begin{tabular}{|c|c|c|c|c|c|}
\hline \multicolumn{6}{|c|}{ Закінчення таблиці 1} \\
\hline $\begin{array}{l}\text { Площа ядер колоноцитів, } \\
\text { мкм }^{2}\end{array}$ & $22,7 \pm 4,8$ & $22,0 \pm 4,2$ & $23,4 \pm 2,4$ & $27,0 \pm 4,4$ & $21,4 \pm 4,4$ \\
\hline $\begin{array}{l}\text { Площа келихоподібних } \\
\text { клітин, } \text { мкм }^{2}\end{array}$ & $82,1 \pm 10,2$ & $69,4 \pm 18,0$ & $75,3 \pm 21,8$ & $71,9 \pm 8,4$ & $70,6 \pm 21,6$ \\
\hline $\begin{array}{l}\text { Відносна кількість } \\
\text { келихоподібних клітин, \% }\end{array}$ & $26,7 \pm 3,2$ & $28,8 \pm 1,4$ & $26,5 \pm 3,4$ & $27,5 \pm 3,8$ & $28,0 \pm 1,2$ \\
\hline Мітотичний індекс, \% & $5,2 \pm 0,8$ & $5,0 \pm 1,4$ & $4,1 \pm 0,8$ & $5,1 \pm 0,6$ & $3,5 \pm 0,8^{*}$ \\
\hline $\begin{array}{l}\text { Відносна кількість } \\
\text { біфуркаційних крипт, \% }\end{array}$ & $5,7 \pm 2,6$ & $7,0 \pm 1,2$ & $7,1 \pm 0,8$ & $3,2 \pm 1,0$ & $5,0 \pm 2,4$ \\
\hline
\end{tabular}

${ }^{*} \mathrm{p} \leq 0,05$ порівняно $з$ контролем

Вплив Д1 на слизову оболонку низхідної ободової кишки щурів при виразковому коліті

При дії Д1 у слизовій оболонці низхідної ободової кишки спостерігалися дифузна десквамація та незначна дистрофія поверхневого епітелію. Вираженими були зміни у мікроциркуляторному руслі гіперемія, стаз крові у капілярах та крововиливи. Крововиливи були різної форми та величини (енхімози) і розвивалися безпосередньо від слизової оболонки аж до підслизової основи. Однак крововиливи можуть бути наслідком не впливу Д1, а руйнування слизової оболонки через хімічний опік, а запалення $\epsilon$ реакцією організму на цей опік. Також спостерігалися незначні скупчення поліморфно-ядерних лейкоцитів й одиничні лімфоцити і гістіоцити у підслизовій основі. У серозній оболонці була помітна лімфо-інфільтрація. Під час аналізу даних морфометрії встановлено вірогідне зростання товщини слизової оболонки на 31,8 \% (табл. 1) порівняно $з$ показниками контрольної групи, що може бути пов'язане з активацією захисних процесів у слизовій оболонці ободової кишки. Д1 також сприяв зникненню ознак атипії колоноцитів та нашарувань на поверхні слизової оболонки, однак не впливав на інтенсивність запального процесу та десквамацію епітелію.

Отримані дані свідчать, що Д1 за умов впливу протягом двох тижнів на тлі експериментального коліту викликає зміни слизової оболонки у вигляді запального процесу, порушення мікроциркуляторного русла (гіперемія) та розростання лімфатичної тканини (зростання кількості Т- і В-лімфоцитів), тобто зміни, подібні до таких за умов експериментального коліту $[1 ; 3 ; 7 ; 28]$.

Вплив MI-1 на слизову оболонку низхідної ободової кишки щурів при виразковому коліті.

За умов дії МI-1 на тлі експериментального коліту мали місце скупчення лімфоцитів у власній пластинці слизової оболонки ободової кишки, деякі порушення з боку судинного русла у вигляді еритростазу, незначних діапедезних крововиливів. Також за умов дії MI-1 зникала десквамація поверхневого епітелію, зменшувалось запалення слизової оболонки (порівняно з групою з експериментальним колітом). Морфометричні показники слизової оболонки вірогідно не відрізнялися від контрольних. Описані зміни можуть свідчити, що похідне піролу MI-1 при дії за умов експериментального коліту пригнічує запальний процес та сприяє збереженню цілісності поверхневого епітелію слизової оболонки ободової кишки.

Таким чином, цитостатична сполука MI-1 при дії за умов коліту виявляла протизапальні та протекторні властивості щодо слизової оболонки ободової кишки, що узгоджується з нашими попередніми даними $[16 ; 19 ; 20]$, а тому є перспективним засобом для терапії запальних захворювань кишечника.

Сумісний вплив МI-1та Д1 на слизову оболонку низхідної ободової кишки шурів при виразковому коліті.

Сумісна дія досліджуваних похідних піролу за умов коліту викликала зміни слизової оболонки низхідної ободової кишки щурів, подібні до таких при індукції коліту без інших втручань: дифузне злущення поверхневого епітелію, набряк власної пластинки, гіперемія та стаз крові у капілярах. Також спостерігалося потовщення м'язового шару, що може бути ознакою спазму кишкової стінки. У серозному шарі були помітні крововиливи, тромби та лімфо-інфільтрація. При аналізі даних морфометрії було показано вірогідне зростання товщини слизової оболонки на $34,4 \%$ та зменшення мітотичного індексу клітин крипт на 32,6 \% (табл. 1), що свідчить про активацію захисних процесів у слизовій оболонці та пригнічення проліферативної активності клітин. Таким чином, при сумісній дії досліджуваних сполук за умов коліту ступінь запалення слизової оболонки та десквамації епітелію залишається на рівні групи коліту, тобто терапевтичного ефекту не спостерігалося. Подібні зміни були характерні для групи коліт+Д1, тобто за умов сумісної дії Д1 та МI-1 ефекти Д1 домінують. 
Висновки й перспективи подальших досліджень. Похідне піролу МI-1 за умов експериментального коліту сприяє зменшенню вираженості ознак запалення у слизовій оболонці низхідної ободової кишки, зникненню десквамації поверхневого епітелію, тобто виявляє лікувальні властивості при запальних захворюваннях кишечника.

Похідне піролу Д1 за умов коліту на десквамацію поверхневого епітелію та ознаки запалення у слизовій оболонці низхідної ободової кишки не впливає, проте сприяє зникненню ознак атипії колоноцитів та нашарувань на поверхні слизової оболонки.

При сумісній дії Д1 та МІ-1 за умов коліту зміни слизової оболонки низхідної ободової кишки подібні до таких при дії Д1 окремо, також має місце пригнічення проліферативної активності клітин.

Максимальний протизапальний та захисний ефект щодо слизової оболонки низхідної ободової кишки при застосуванні за умов експериментального коліту виявляє похідне піролу МI-1, тоді як захисна дія Д1 та комбінації Д1 і МІ-1 є значно слабшою.

Дослідження похідних піролу є перспективними сполуками для створення протипухлинних засобів на їхній основі, а також для попередження розвитку передпухлинних захворювань, таких як виразковий коліт.

\section{Джерела та література}

1. Воробьев Г. И. Неспецифические воспалительные заболевания кишечника / Г. И. Воробьев, И. Л. Халиф. М. : Миклош, 2008. $-400 \mathrm{c}$.

2. Kaser A. Inflammatory Bowel Disease / A. Kaser, S. Zeissig, R. Blumberg // Annu. Immunol. - 2010. - Vol. 28. P. 573-621.

3. Адлер Г. Болезнь Крона и язвенный колит : пер. с нем. - М. : ГЕОТАР-МЕД, 2001. -527 с.

4. Daniel K. Podolsky Inflamatory bowel disease // New Eng. J. Med. - 2002. - Vol. 347, № 6. - P. 417-429.

5. Xie J. Cancer in inflammatory bowel disease / J. Xie, S. H. Itzkowitz // World J Gastroenterol. - 2008. - Jan 21. 14(3). - P. 378-389.

6. Ullman T. A., Itzkowitz S. H. Intestinal inflammation and cancer / T. A. Ullman, S. H. Itzkowitz // Gastroenterology. - 2011. - May. - 140(6). - P. 1807-1816.

7. Jain S.K. Inflamatory bowel disease and colon cancer: a review / S. K. Jain, M.A. Peperson // Dig. Dis.Sci. 1997. - Vol. 15. - P. 243-252.

8. Гарманчук Л. В. Производное малеимида 1-(4-Сl-бензил)-3-Сl-4-(CF3-фениламино)-1Н-пиролл-2,5-дион как эффективный и малотоксичный цитостатик / Л. В. Гарманчук, О. В. Линчак, В. В. Никулина [та ін.] // Экспериментальная и клиническая фармакология. - 2013. - Т. 76, № 8. - С. 39-42.

9. Garmanchuk L. V. MI1 - derivative of maleimide inhibits cell cycle progression in tumor cells of epithelial origin / L. V.Garmanchuk, V. K. Ribalchenko, L. I. Ostapchenko [et al.] // Biopolymers and Cell. - 2013. Vol. 29, № 1. - P. 70-74.

10. Kuznietsova H. M. Impact of dihydropyrrol derivative in the normal colonic mucosa of DMH-induced colon cancer rats compared with 5-fluorouracil / H. M. Kuznietsova, O. V. Ogloblya, V. K. Rybalchenko // Experimental Oncology. - 2013. - Vol. 5, № 1. - P. 25-29.

11. Имянитов Е. Н. Общие представления о таргентной терапии / Е. Н. Имянитов // Практ. онкология. 2010. - T. 11, № 3. - C. 123-130.

12. Tsai C.-J. The molecular basis of targeting protein kinases in cancer therapeutics / C.-J. Tsai, R. Nussinov // Seminars in Cancer Biology. - 2013. - Vol. 23, I. 4. - P. 235-242.

13. A. Del Prete Molecular pathways in cancer-related inflammation. / A. Del Prete, P. Allavena, G. Santoro et al. // Biochemia Medica. - 2011. - 21(3). - P. 264-275.

14. Wollin L. Antifibrotic and anti-inflammary activity of the torosine kinase inhibitor nintedanib in experimental models of lung fibrosis / L. Wollin, I. Maillet, V. Quesniaux et.al. // J. Pharmacol. Exp. Ther. - 2014. - May. -349 (2). - P. 209-220.

15. Зайцев В. Г. Связь между химическим строением и мишенью действия как основа классификации антиоксидантов прямого действия. / В. Г. Зайцев, О. В. Островский, В. И. Закревский // Экспериментальная клиническая фармакология. - 2003. - № 4. - С. 66-70.

16. Кузнсцова Г. М. Вплив похідних дигідропіролу та малеіміду на стан печінки і товстої кишки щурів у нормі та в умовах індукованого диметилгідразином колоректального раку / Г. М. Кузнєцова, О. В. Линчак, В. К. Рибальченко [та ін.] // Укр. біохім. журн. - 2013. - Т. 85, № 3. - С. 74-84.

17. Yablonska S. Manifestation of antiproliferative effects of new kinase inhibitor in respect of normal cell / S. Yablonska, O. Lynchak, O. Filinska // The FEBS Journal. - 2009. - Vol. 276, № 1. - P. 352. 
18. Гарманчук Л. В. Цитотоксичний вплив на пухлинні клітини in vitro агентів 3 протипухлинним та антиметастатичним ефектом / Л. В. Гарманчук, Н. В. Сенчило, В. В. Нікуліна [та ін.] // Фізика живого. 2011. - Т. 19, № 2. - С. 51-53.

19. Бабута О. М. Гістологічна характеристика слизової оболонки сліпої кишки щурів після впливу МI-1 та 5-фторурацилу при хемоіндукованому канцерогенезі / О. М. Бабута, О. В. Линчак, В. К. Рибальченко // Вісник проблем біології і медицини. - 2013. - Вип. 3, т. 1 (102). - С. 31-35.

20. Линчак О. В. Морфо-функціональний стан органів шлунково-кишкового тракту після впливу похідного малеіміду МI-1 протягом місяця / О. В. Линчак, Г. В. Островська, В. К. Рибальченко [та ін.] // Сучасні проблеми токсикології. - 2011. - Т. 2, № 1. - С. 52-55.

21. Пат. на корисну модель № 22204 (UA), Аб1К31/40. Сполука 1,4-заміщених 5-аміно-1,2-дигідропірол3-онів, що має протиракову активність / Г. Г. Дубініна, Ю. М. Воловенко; заявник і власник Г. Г. Дубінінна, Ю. М. Воловенко. - № u200601855; заявл. 21.02.2006; опубл. 25.04.2007, бюл. № 5.

22. Nalini N. Chemopreventive efficacy of hesperetin (citrus flavonone) against 1,2-dimethylhydrazine-induced rat colon carcinogenesis. / N. Nalini, S. Aranganathan, J. Kabalimurthy // Toxicol. Mech. Methods. - 2012. 22(5). - Р. 397-408.

23. Кузнєцова Г. М. Вплив цитостатика похідного дигідропіролу на слизову оболонку кишечника щурів на тлі оксидативного стресу / Г. М. Кузнєцова, А. Т. Воловненко, Г. В. Островська та ін. // Доповіді НАН України. - 2012. - № 2. - С.174-179.

24. Харчук I. В. Стан слизової оболонки товстої кишки щурів під впливом похідного малеіміду з антипроліферативною активністю за умов оксидативного стресу / І. В. Харчук, М. П. Гебура, Т. В. Рибальченко // Доп. НАН України. - 2010. - № 4. - С. 153-157.

25. Filinska O. Effect of maleimide derivative on oxidative stress and glutathione antioxidant system in 1,2dimethylhydrazine induced colon carcinogenesis in rat / O. Filinska, S. Yablonska, S. Mandryk et. al. // Pharmacia. - 2010. - V. XXIII, № 3. - P. 191-195.

26. Горальський Л. П. Основи гістологічної техніки і морфо-функціональні методи досліджень у нормі та при патології / Л. П. Горальський, В. Т. Хомич, О. І. Кононський. - Житомир : Полісся, 2005. - 288 с.

27. Сергиенко В. И. Математическая статистика в клинических исследованиях / В. И. Сергиенко, И. Б. Бондарева. - М. : Гэотар Медицина, 2006. - 304 с.

28. Струков А. И. Патологическая анатомия : учебник / А. И. Струков, В. В. Серов. - 5-е изд., стер. - М. : Литтерра, 2010. - 848 с

Ена Марина, Кузнецова Галина, Рыбальченко Владимир. Морфофункциональное состояние ободочной кишки крыс в условиях действия производных пиррола на фоне экспериментального колита. Исследовано влияние цитостатиков производных пиррола 1-(4-Cl-бензил)-3-C1-4-(CF3-фениламино)-1Нпиррол-2,5-диона (МИ-1) и 5-амино-4-(1,3-бензотиазол-2-ил)-1-(3-метоксифеніл)-1,2-дигідро-3Н-пірол-3-ону (Д1) при отдельном и совместном действии на морфофункциональное состояние слизистой оболочки ободочной кишки крыс в условиях развития экспериментального колита. Установлено, что М1 является более эффективным и менее токсичным для слизистой оболочки по сравнению с Д1 и комбинации Д1 и МИ-1.

Ключевые слова: слизистая оболочка, ободочная кишка, производные пиррола, экспериментальный колит.

Yena Maryna, Kuznietsova Halyna, Rybalchenko Volodymur. Pyrrole derivatives effect on morphofunctional state of the rats colon with experimental colitis. We've studied individual and joint effect of pyrrole derived cytotoxic drugs i.e.1-(4-Cl-benzyl)-3-Cl-4- $\left(\mathrm{CF}_{3}\right.$-phenylamino)-1H-pyrrol-2,5-dione (MI-1) and 5-amino-4(1,3-benzothyazol-2-yl)-1-(3-methoxyphenyl)-1,2-dihydro-3H-pyrrol-3-one (D1) on the morpho-functional state of colon mucosa in rats with experimental colitis. It was found that M1 was more effective and less toxic to mucosa as compared to D1 and a combination of D1 and MI-1.

Key words: mucosa, bowel, pyrrole derivatives, experimental colitis.

Стаття надійшла до редколегії 23.01.2015 p. 